nor are the subjects arranged in alphabetical order usual in a book for occasional reference. It is a little of a shock to turn from mineral resources to population, from great cities to the native Indians, and from commerce to Alaska; even although each chapter in itself is excellent reading.

Mr. Gannett was evidently anxious to resist the temptation of enlarging unduly upon his own special subject, and he has in our opinion gone to the opposite extreme, and lost an opportunity of showing how completely the structure of the country determined by its geology dominates the whole geography of the United States. The introductory chapter does contain a good deal of geology in relation to the configuration of the different natural regions, but the connecting links with the other distributions are wanting. It would be better in a book intended primarily for the general English reader to translate the statistics so freely given into the usual British units of weight and money; the "short tons" for coal and "Iong tons" for iron.ore are puzzling, and make

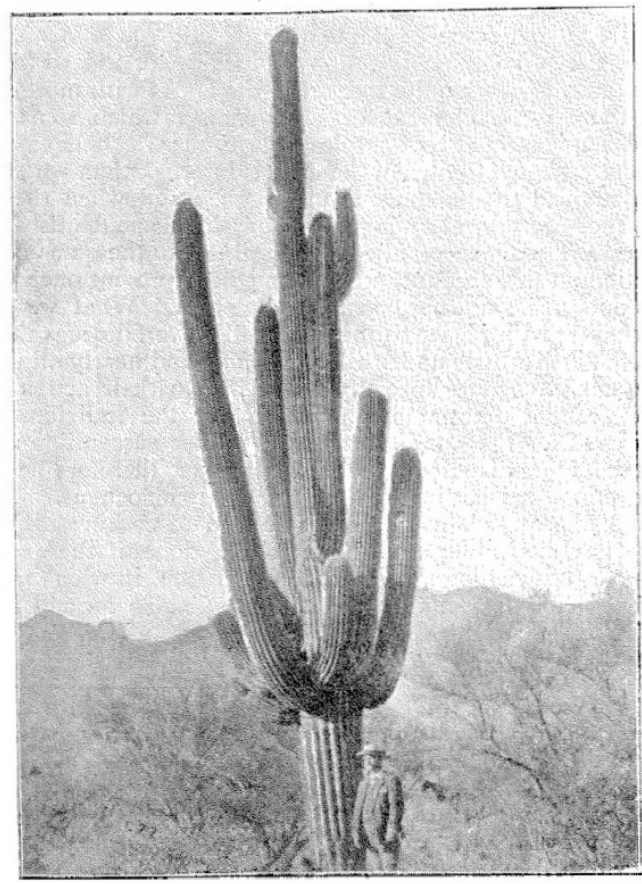

FIG. x.-The Giant Cactus of the Arid Region.

comparison with other countries difficult. Besides, it would greatly assist the clear conception of such statistics if they were expressed in round numbers.

Apart from these possibilities for improvement, the book contains nothing which we cannot heartily praise. The revision of the text is very thorough, and we have not detected a single erratum.

Many of the topics are handled with surprișing freshness, and many interesting points are brought out, such as the changed manner of life of the liardy fishers of the New England coast, who have found an easy and profitable calling as caterers for holiday-makers from the great cities. The author discusses the whole question of American cities, showing how the convenience of the rectangular plan has outweighed asthetic considerations ; and explaining the relative backwardness of the old cities of the east, compared with the new growths of the west, by the vast amount of capital locked up in such archaic conveniences as gas-works and horse or cable cars, while the untrammelled new municipalities can No. I 508 , vOL. 58 ] establish electric power-houses at once for all needs. So, too, he shows that no country in the world possesses so many ruined cities as the United States-not only the abodes of the early mound-builders and cliff-dwellers, but ruins of yesterday; mushroum towns that teemed with busy thousands in a year, and were abandoned in a month on the failure of a mine or of a company, leaving only "a history of disappointed hopes, of hardships and struggles."

The movements of population are well treated, and a map showing the areas where more than ro per cent. of the population are foreign-born, and those where more than Io per cent. of the population are of negro race, displays the interesting fact that the former occupies the whole, north and west, the latter the whole south-east, leaving a narrow belt between the two areas. The number of original statistical and physical maps is one of the most striking and satisfactory features of the book, and the illustrations also are admirably selected. At a time when the United States are entering on a new era

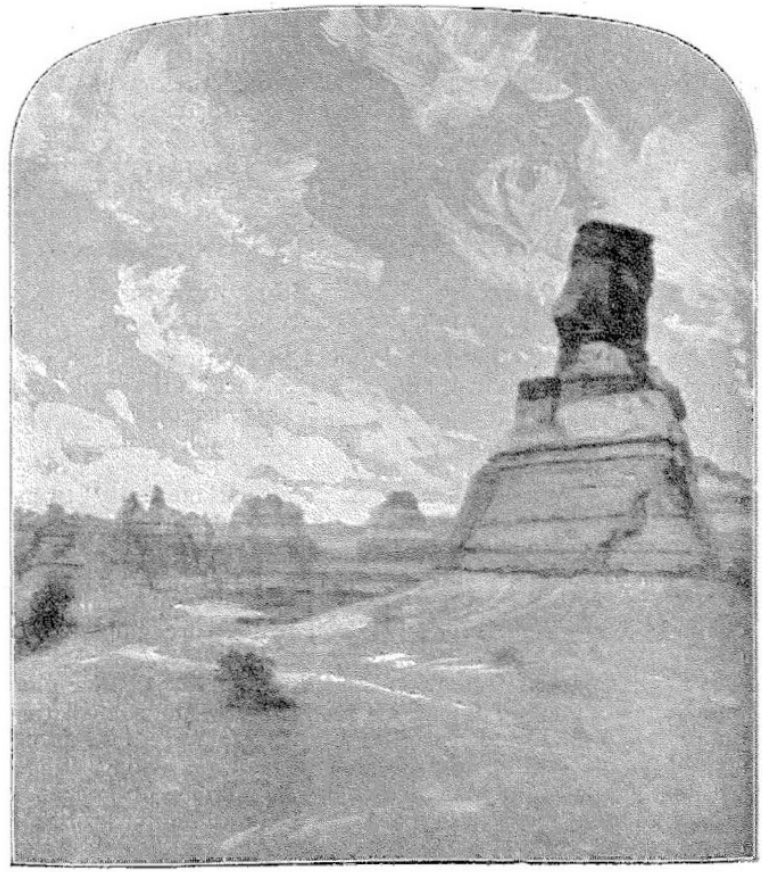

Fig. 2.-Buttes in the Plateau Region.

of their national life, the publication of so accurate and impartial an account of that great country by one of its own citizens is peculiarly appropriate, and deserves a cordial welcome. HUgh ROHERT MILL.

\section{THE BRITISH ASSOCIATION.}

THE concluding meeting of the British Association was held on Wednesday, September I4. Sir William Crookes occupied the chair, and the Mayor of Bristol (Sir R. H. Symes) and the High Sherifi were present, as well as the principal officers and members of the Association. The following report of the mecting is from the Times:-

The proceedings were opened by the announcement that the general committee had been able to pass grants to the amount of $1485 l$. - - an amount which was justified largely by the success of the present meeting.

Sir Norman Lockyer proposed that the thanks of the Association be given to the Mayor, the High Sheriff, the 
executive committee, and the local officers. He said that the great success of the meeting was largely due to the efforts of those referred to in the resolution. Never before in his experience of the Association had local effort led to such absolute smoothness in the working of the machine. It was a pity that the work of the Association had been so hard as to prevent many members from seeing all the points of interest in this interesting city of Bristol. The magnificent educational establishments which crowded the city were themiselves worthy of close attention, and at some future meeting the IBritish Association might find Bristol at the head of some great southwestern University.

Prof. Schäfer seconded the resolution.

Mr. James Scott (of Toronto), on behalf of the Canadian members, expressed high appreciation of the welcome which had been accorded to them.

The resolution was then carried with much enthusiasm.

The Mayor of Bristol, Mr. Howell Davis (chairman of the executive committec), Mr. Arrowsmith (local treasurer), and Mr. Arthur Lee and Dr. Bertrain Rogers (local secretaries), each responded, Mr. Arrowsmith expressing lis acknowledyments for the cheque for $120 l$. which had been given by the Council of the Association towards the Colston Hall fund.

Prof. Rücker next moved a comprehensive vote of thanks to all public bodies and private persons who had contributed to the success of the meetingr. He said that if the citizens of Bristol had not supported the local officers, the success of the meeting could not have been secured in so large a measure. As President of the International Committee of the Magnetic Conference, he was charged to convey the best thanks of the foreign members to the Association and to the local authorities for the extreme kindness of their reception.

Dr. Gladstone seconded the resolution, which was carried unanimously, the High Sheriff responding.

Sir John Evans moved a cordial vote of thanks to Sir William Crookes, President, for his admirable address and for his conduct in the chair. He proplesied, when introducing Sir Williain to the cluair, that the Association would hear from hin a remarkable address, and that proplecy had been amply justified. One of the most valuable portions of that address was that in which public attention was called to the fact that there was in our atmosphere an inexhaustible supply of nitrogen, and that means should be discovered for employing that nitrogen to increase the produce of the earth. Sir William Crookes had fulfilled with courtesy and distinction all the many and various duties which the past week had imposed upon hin, and the thanks of the Association were cordially due to him.

P'rof. Roberts-Austen seconded the resolution, which was carried with enthusiasm.

Sir IV. Crookes, in responding, said that he felt like an clectrical switch-board-for really he was only the transmitter and distributor of these thanks to those whose help had been so material. He was especially grateful to the Mayor and Mayoress, whose hospitality had facilitated his work so greatly; and he regarded as one of the lighest complinents ever paid to him the invitation to the remarkable snoking-symposium of the previous Friday evening. As for the President's office, the pace was getting too fast for human endurance; and in a short time the British Association would, if the work were to be got through at all, have to elect a young athletic man of five-and-twenty instead of a man over three-score years and ten.

Prof. Rücker announced that the number of tickets issued for the present meeting of the Association was $2+46$.

This concluded the proceedings. The next meeting will be held at Dover, and will conmence on September 13 , I 899 .

No. I 508, voI. $5 S]$

\section{SECTION D.}

zOOLOGY.

Opexixg Address by Prof. W. F. R. WeldoN, M.A., F.R.S., Presidext of the Section.

Ix attempting to choose the subject of the address with which custom obliges your president to trouble you, I felt that I should have the best hope of interesting you if I decided to speak to you on the subject most interesting to myself. I therefore propose to discuss, as well as I can, the principal objections which are urged against the theory of Natural Selection, and to describe the way in which I think these objections may be met.

The theory of Natural Selection is a theory of the importance of differences between individual animals. In the form in which Darwin stated it, the theory asserts that the smallest observable variation may affect an animal's chance of survival, and it further asserts that the magnitude of such variations, and the frequency with which they occur, is governed by the law of chance.

Three principal objections are constantly brought forward against this theory. The first is that the species of animals which we know fall into orderly series, and that purely fortuitous variations cannot be supposed to afford opportunity for the selection of such orderly series; so that nuany persons feel that if the existing animals are the result of selection aniong the variable offspring of ancestral creatures, the vari. ations on which the process of Natural Selection had to act must have been produced by something which was not chance.

The second objection is that minute structural variations can. not in fact be supposed to affect the death-rate so much as the theory requires that they should. And it is especially urged that many of the characters, by which species are distinguished, appear to us so small and useless that they cannot be supposed to affect the chance of survival at all.

The third objection is that the process of evolution by Natural Selection is so slow that the time required for its operation is longer than the extreme limit of time given by estimates of the age of the earth.

Now the first of these three objections, the objection to fortuitons variation as the source of material on which Natural Selection can act, is very largely due to a misunderstanding of the meaning of words. The meaning of the word Chance is so thoroughly misunderstood by a number of writers on evolution that I make no apology for asking you to consider what it. does mean.

Consider a case of an event which happens by chance. Suppose I toss a penny, and let it fall on the table. You will agree that the face of the penny which looks upwards is determined by chance, and that with a symmetrical penny it is an even chance whether the "head" face or the "tail" face lies uppermost. For the moment, that is all one can say about the result. Now compare this with the statements we can make about other moving bodies. Y'ou will find it stated, in any almanac, that there will be a total eclipse of the moon on Decenber 27, and that the eclipse will become total at Greenwich at $10.57 \mathrm{p.m}$. ; and I imagine you will all feel sure, on reading that statement, that when December 27 comes the eclipse will occur; and it will become total at 10.57 p.m. It will not become total at 10.50 p.m., and it will not wait until 11.0 p.m. You will say, therefore, that eclipses of the moon do not occur by chance.

What is the difference between these two events, of which we say that one happens by chance, and the other does not? The difference is simply a difference of degree in our knowledge of the conditions. The laws of motion are as true of moving pence as they are of moving planets; but it happens that we know so much about the sun, and the earth, and the moon, that we know the circumstances which affect their relative positions very accurately indeed; so that we can predict within less than a minute the time at which the shadow of the earth will next fall upon the moon.

But the result of tossing a penny depends upon a very large number of things which we do not know. It depends on the shape and mass of the penny, its velocity and direction when it leaves one's hand, its rate of rotation, the distance of one's hand from the table, and so on. If we knew all these things before tossing the penny, we should be able to predict in each case what the result would be, and we should cease to regard pitch and toss as a game of chance.

As it is, all we know about these complicated conditions is that if we tuss a penny for a number of times, the conditions 
which give "heads" will occur about as often as the conditions which give " tails."

If you examine any event which occurs by chance, you will find that the fortuitous character of its occurrence always depends upon our ignorance concerning it.

If we know so little about a group of events that we cannot predict the result of a single observation, although we can predict the result of a long series of observations, we say that these events occur by chance. And this statement seems to me to contain the best definition of chance that can be offered.

If we used the word chance in this sense, we see at once that our knowledge of animal variations is precisely knowledge of the kind referred to in our definition of chance. We know with some certainty the average characters of many species of animals ; but we do not know exactly the character of the next individual of these species we may happen to look at. So that in the present state of our knowledge it is à priori certain that the great majority. of animal variations should occur by chance, in the sense in which we have used the phrase; and I will show you in a moment illustrations of the fact that they do so occur.

But before doing so, I would point out the difference between the sense in which we have used the word chance, and the sense in which it is used by many objectors to the theory of Natural Selection. Such epithets as blind, laviless, and the like, are constantly applied to chance; and a kind of antithesis is established between events which happen by chance, and those which happen in obedience to natural laws. In many Gernan writings, especialls; this antithesis between Zufulligkeit and Gesetzmassigkeit is strongly insisted upon, whenever organic variation is discussed.

This view of chance is not supported by experience; and in deed, if it could be shown that any thing in human experience were absolutely lawless, if it could be shown that in any department of nature similar conditions did not produce similar effects, the whole fabric of human knowledge would crumble into chaos, and all intellectual effort would be a profitless waste of : time. There is, not the slightest reason to believe that any such absolutely lawless phenomena do exist in nature; so that : we need pay no'further attention to the writers who assume that chance is a lawless thing.

But if chance is a perfectly orderly and regular phenomenon, then the question, whether animal variations occur by chance or not, can be; settled by direct observation. I will now show you one or two exanples of erents which undoubtedly occur by chance, and then conpare these with one or two cases of organic variation.

As erents which occur by chance, I have taken the results of tossing twelve dice. My wife has spent some time during the last two months in tossing dice for you, and I will ask you to look at the,results.

Her fyrst record gives the number of dice showing more than three points in each of 4096 throws of twelve dice. There are, of course, six numbers on each of the : dice; so that if all the dice were perfectly symmetrical and similar, the average number of dice with more than three points should be six in each throw of twelve. But dice are not symmetrical and similar. The points on the dice used were marked by little holes, scooped out of their faces; and the face with six such holes scooped out of it was opposite to the face with only one such hole: so that the face with one point was heavier than the face with six points; and therefore six was rather more likely to be uppernost than one. In the same way, two was opposite five; so that the five face was a little more likely to fall uppermost than the face with two points. Therefore, it is a little nore likely that you will throw four, five, or six, in throwing dice, than it is that you will throw one, two, or three.

Accordingly, the average number of dice, in these 4096 throws, which had more than three points, was not six, but $6 \cdot 135$.

To show you that this excess of high points was due to some permanent property of the dice, she threw these twelve dice another 4096 times; and the average number of dice with more than three points was 6.139 . A third series of trials gave an average of 6.104 , and a fourth gave an average of 6.116 .

You sce that the difference between the highest and the lowest of these determinations is only about one-half per cent., so that the mean result of such a series of fortuitous events can be determined with great accuracy.

And just as the mean of the whole series can be determined, so we can know with considerable accuracy how often any No. I 508 , voL. 58$]$ possible deviation from the average result will occur. The degree of accuracy with which we can know this may be judged from. Table I.

TABLE I.-Frequency with which Dice showing more than three Points were throw't in each of Four Sernes of Trials, the number of throw's in each Series being $2^{12}=4096$.

\begin{tabular}{|c|c|c|c|c|c|}
\hline \multirow{2}{*}{$\begin{array}{l}\text { Number of } \\
\text { dice with } \\
\text { more than } 3 \\
\text { points. }\end{array}$} & \multirow{2}{*}{$\begin{array}{l}\text { Most probable } \\
\text { frequency } \\
\text { for symmetri- } \\
\text { cal dice. }\end{array}$} & \multicolumn{4}{|c|}{ Observed frequencies. } \\
\hline & & s. & II. & ist. & w. \\
\hline 12 & I & 0 & I & 0 & I \\
\hline II & 12 & II & 13 & 8 & 14 \\
\hline io & 66 & 71 & 86 & 61 & 66 \\
\hline 9 & 220 & 257 & 246 & $24 \mathrm{I}$ & 241 \\
\hline 8 & 495 & 536 & 540 & $5^{13}$ & 586 \\
\hline 7 & 792 & 847 & 836 & 856 & 861 \\
\hline 6 & 924 & 948 & 913 & ${ }_{94} \mathrm{~S}$ & 866 \\
\hline 5 & 792 & 731 & 750 & So 2 & $72 \mathrm{~S}$ \\
\hline 4 & 495 & 430 & 446 & 420 & 474 \\
\hline 3 & 220 & IgS & IgS & I 82 & 204 \\
\hline 2 & 66 & 60 & 55 & $5^{1}$ & 67 \\
\hline I & 12 & 7 & 12 & 13 & 6 \\
\hline 0 & I & 0 & 0 & I & o \\
\hline
\end{tabular}

You see that the results of the experiments agree fairly well with one another, and differ from the results most probable with symmetrical dice, in the way which the structure of the actual dice would lead one to expect. Throws which give seven, eight, or nine dice with more than three points occur too often, throws in which only two, three, or four dice have more than three points do not occur often enough. You see then that each of these results is orderly and regular, and that the four results agree very fairly among thenselies, not only in the mean value of each of them, but in the magnitude and frequency of departures from the nean. That they differ from the results which would probably be obtained with symmetrical and sinilar dice is only to be expected, because the dice used are neither symmetrical nor similar.

You notice that this table is very nearly synmetrical; the most frequent result is that which lies in the middle of the series of possible results; and the other frequencies would, with perfect dice, be distributed symmetrically on each side of it ; so that with perfect dice one would be as likely to throw five dice out of twelve with more than three points as one would be to throw seven, and so on.

This symmetry in the distribution of the results is only found when the chance of the event occurring in one trial is even. The next table shows the result of 4096 throws of twelve dice,

TABLE II:-Frequency of Sixes in 4096 throws of Täelie Dice.

\begin{tabular}{c|c|c}
\hline Number of sixes. & $\begin{array}{c}\text { Most probable number with } \\
\text { symmetrical dice. }\end{array}$ & Number observed. \\
\hline 8 & 0.58 & 1 \\
7 & 4.66 & 7 \\
6 & 27.18 & 24 \\
5 & 116.43 & 115 \\
4 & $363^{\circ} .84$ & 350 \\
3 & $803^{\circ} 53$ & 796 \\
2 & $1211^{\circ} .44$ & 1181 \\
1 & 1102.56 & 1145 \\
0 & 459.52 & 447 \\
\hline
\end{tabular}

in which sixes only were counted. The chance against throwing six with any one of the dice is of course five to one; so that in throwing twelve dice you are more likely to throw two sixes than to throw any other number. But you see that the chance of throwing only one six is very much greater than the chance of throwing three; the chance of throwing none is greater than the chance of throwing four, and while there is a chance of throwing five, six, or more, of course it is impossible to throw less than none at all; so that the diagram is all askew. You see that this time, as before, the frequency with which any 
number of sixes did actually occur was as near to the 1tsult most probably with perfect dice as the asymnetry of the actual dice allows one to expect. ${ }^{1}$

These results will be enough to show you how absurd is the attitude which so many writers have taken up towarls chance when discussing animal variation. The assertion that organic variation occurs by chance is simply the assertion that it obcys a law of the same kind as that which expresses the orderly series of results we have just looked at.2

That is a matter which can be settled by direct olservation. But in order to express the law of chance in such a way that we can apply it to animal variation, we must nake use of a trick which mathematicians have invented for that purpose.

It is a well-known proposition in prolability that the fre. quency with which one throws a given number of sixes in a series of trials with twelve dice is proportional to the proper term in the expansion of $\left(\frac{1}{6}+\frac{3}{6}\right)^{12}$. The values in this table were calculated by expanding this expression. But if I had wanted to show you the most prolable result of ex. periments with 100 dice, I should not willingly have expanded $\left(\frac{1}{6}+\frac{5}{6}\right)^{100}$. The labour would be too enornous. Then again, suppose ue are given a number of results, and are not told how many dice were used, how are we to find ont the poucr to which we must raise $\left(\frac{1}{6}+\frac{5}{6}\right)$, since this depends on the number of dice?

Before applying thc law of chance to variations in which we cannot directly neasure the number of contributory causes (the analogue of the number of dice), we nuust find some way out of this difficulty.

The way is shown by the diagram (Fig. 1).

The rectangles in this diagram are proportional to the various ternis of $\left(\frac{1}{2}+\frac{1}{2}\right)^{12}$; and they represent the most probable result of counting the number of dice with more than three points in a series of trials with treelve dice. The heights of these rectangles were determined by expanding $\left(\frac{1}{2}+\frac{1}{2}\right)^{12}$; but you notice the dotted curve which is drawn through the tops of them. The general slope of this curve is, you see, the same as the general slope of the series of rectangles; and the area of any strip of the curve which is bounded by the sides of a rectangle is very nearly indeed the same as that of the rectangle itself.

The constants upon which the shape of this curve depends are easily and quickly obtained from any series of observations; so that you can easily and quickly see whether a set of observed phenomena obeys the synmetri. cal law of chance or not.

A good many characters of animals do vary in this symmetrical way; and I show you one, which will always be historically interesting, because it was one of the principal characters used to illustrate MIr. Galton's invaluable applications of the law of chance to biological problems. That is the case of human stature. The diagram (Fig. 2) shows the stature of 25,878 American recruits; and you see that the frequency with which each stature occurs is very close indeed to that indicated by the curve. So that variations in human stature do occur by chance, and they occur in such a way that variation in either direction is equally probable.

In cases where a variation in either direction is equa!ly likely to occur, this symmetrical curve can be used to express the laiv

1 It is unfortunate that $\mathrm{I}$ chose dice as instruments in these experiments. Dice are not only sensibly asymmet rical, but any ordinary dice are sensibly dissimilar; so that the result most probable with any actual dice is not given by a simple binomial expansion. The result theoretically most probable for the actual dice usel could not be determined without very careful measurement of the dice themselves; and I was unable to attempt measures of the ment of the dice themselves; and I was unable to attempt measures of the
requisite accuracy. All that the records show, as they stand, is the amount requisite accuracy. All that the records show, as they stand, is the amount

of arreement between four successive observations of a furtuit sus event

The law is not, however, identical in the two cases; see infra.

NO. I 508, VOL. 58] of distribution of variations. And the great difficulty in applying the law of chance to the treatment of other cases was, until quite lately, that the way of expressing asymmetrical distribu. tiuns by a similar curve was unknown; so that there was noolvious way of determining whether these asynnmetrical distributions ol,eyed the law of chance or not.

The forn of the curve, related to an asymmetrical distribution of chances, as the curve before you is related to symmetrical distributions, was first investigated by nyy friend and colseague Prof. Karl Pearson. In 1895 Prof. I'earson pablished an account of asynmetrical curves of this kind, and he showel the way in which these curves inight be applied to practionl statistics. Ife illustrated his renarkable menoir by showirer that several cases of organic variation could be easily formulated by the method he clescribed: and in this way he made it possible to apply the theory of chance to an enormous mass of material, which no one had previously been alile to reduce to an orderly and intelligible form.

In this same memoir Prof. Pearson dealt with anoiher 
chance whether you draw a red card or a black one. Suppose you draw a red card, and keep it. The chance that your second card will be red is not so great as the chance that it will be black; because there are only twenty $y$-five red cards and twentysix black cards left in the pack.

Now Prof. Pearson has shown how to deal with cases of this kind also; and how to determine, from the results of statistical observation, whether one is dealing with such cases or not.

I am no mathematician, and I do not dare eren to praise the mathematical process by which this result was achieved. I will only say that it is experimentally justified by the fact that most statistics relating to organic variation are most accurately repre. sented by the curve of frequency which Prof. Pearson deduces for the case where the contributory causes are nutually interdependent. ${ }^{1}$

The first case of an asymmetrical distribution in animals which I ask you to look at is the frequency of variations in the size of part of the carapace of shore crabs. The crabs measured were 999 females from the Bay of Naples. In this case the distribu- series of deviations from the mean length of the antero.lateral margin is as definite a character of the crabs as the mean itself; and in every generation a series of deviations from the mean is regularly produced, according to a law which we can learn if we choose to learn it.

Now suppose it became advantageous to the crabs, from some change in themselves or in their surroundings, that this part of their carapace should he as long as possible. Suppose the crabs in which it. was shorter had a smaller chance of living, and of reproducing. than the crabs in which it was longer.

Suppose that crabs in which this dimension is longest were as much nore productive than those in which it was shortest, as the most prolific marriages are more fertile than the least prolific marriages among ourselves. Prof. Pearson has pointed out that half the children born in England are the offspring of a quarter of the marriages. If we suppose the productiveness anong crabs to vary as much as it does among ourselves, only that in crabs the productiveness is greater, the greater the length of this bit of the carapace, then half of the next

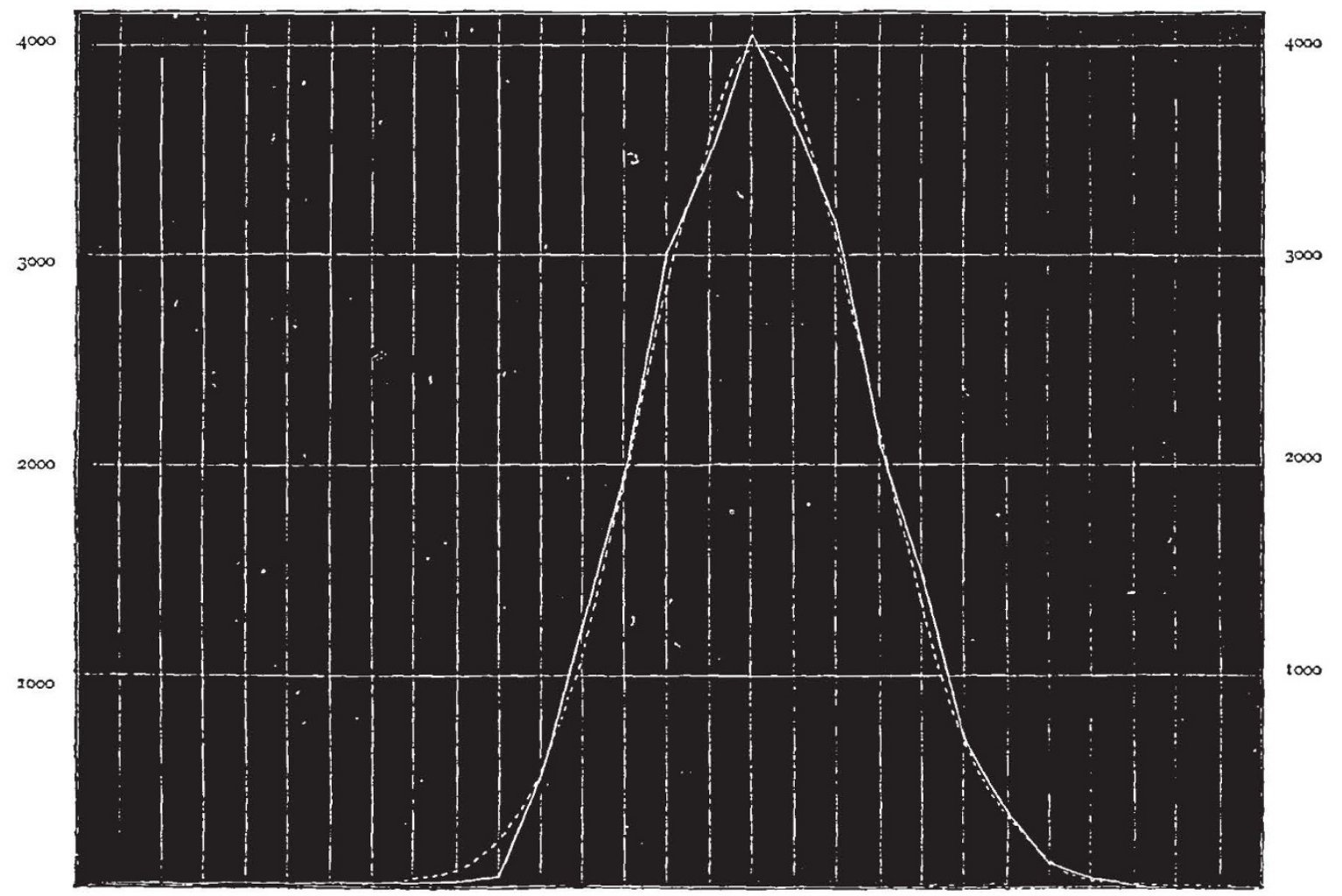

$\begin{array}{lllllllllllllllllllllllllllll}51 & 52 & 53 & 54 & 55 & 56 & 57 & 53 & 59 & 60 & 61 & 62 & 63 & 64 & 65 & 66 & 67 & 68 & 69 & 70 & 71 & 72 & 73 & 74 & 75 & 76 & 77 & 78\end{array}$ Fic. 2.-Diagram showing the height (in inches) of each of 25,873 American recruits.

tion of variations (see Fig. 3) is rery nearly symmetrical, and in an account of these crabs which I wrote before Prof. Pearson's memoir was published, I treated them as symmetrical. The curve actually drawn on the diagram is one constructed by Prof. Pearson himself from the data given by my measurements of the crabs, and it fits the observations very sensibly better than the synmetrical curve. So that this dimension of a crab's carapace does vary by chance, but the chance of a given deviation from the mean length is not quite the same in both directions.

Now, admitting for the moment that these differences in the length of a part of the crab's carapace can affect the crab's chances of survival, you see that natural selection has abundant material un which to work. The production of this regular

1 Eren the distribution of human stature, which has been so successfully. treated by the older, so-called "normal" curve, is more accurately represented by a curve or so that Mr. Galton's practice and Prof. Pearson's theory are alike justified.'

No. I 508 , VOL. 58$]$ generation of crabs will be produced by that quarter of the present generation in which the antero.lateral margin is longest. And as the offspring will inherit a large percentage of the parental character, the mean of the race may be sensibly raised in a single generation.

This riew of the possible effect of selection seens to have escaped the notice of those who consider that favourable variations are of necessity rare, and likely to be swamped by inter. crossing when they do occur. You see that in this case there are a few individuals considerably different from the mean in either direction, and a very large number which differ from the mean a little in either direction. If such deviation be associated with some advantage to the crabs, so that crabs which possess such abnormality are more fertile than those which do not, it is a certainty that the mean character of the next generation will change, if only a little, in the direction advantageous to the race; and the opportunity for selective modification of this kind to occur in either direction is very nearly the same. 
In the next case, this is not true.

The diagram (Fig. 4) represents the number of fenule swine, out of a batch of two thousand examined in Chicago, which have a given number of Mitllerian glands in the right fore-leg.

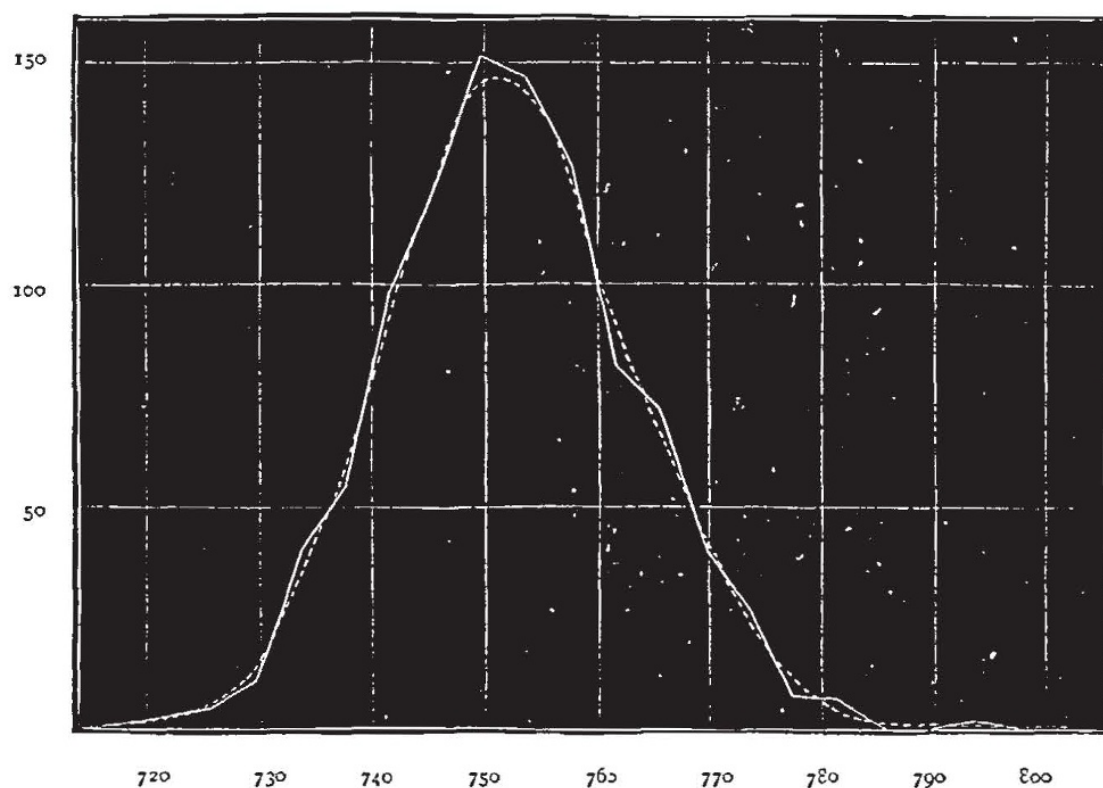

Fig. 3.-Diagram showing the magnitude of the antero-lateral margin (in terms of carapace-length) in 999 female shore-crabs from Naples.

The distribution is much more skew than in the case of the crabs, and you see again the very beautiful way in which P'rof. l'earson's curve expresses it. You see that the range of variation is much greater on one side of the mean than un the other; and the selective destruction necessary in order to raise the mean number of glands by one would be very different from the amount of destruction necessary in order to lower the mean by one. Further, the mean number of glands in these pigs is $3 \frac{1}{2}$; the number which occurs oftenest, the "modal" num. ber as Prof. Pearson calls it, ${ }^{1}$ is three. Now it is im. possible to lower this num. ber till it is less than o, so that it can only be rliminished by three ; but it is conceirable that it should be in. creased by more than three. So that the amount of se lective destruction required in order to change either the mean or the inodal cha. racter of these pigs in one direction, would be greater than the amount required, in order to produce a change of equal magnitude in the opposite clirection, and the

1 All attempts to confine the word "average" to the most frequently: occurring magnilude, and the word "meas " to the arithmetic mean of the series, have failed to secure suppors. Therefore Prof. Pearson's proposal to call the value which occurs oftenest the "mode" is very useful.

NO. I 5O8, VOL. 58] the other. anmount of possible change is greater in one direction than in

Now let us pass on to another example.

Table III. shows the variation in the number of petals in a race of buttercups studied by Prof. de Vries. You see that the most frequent

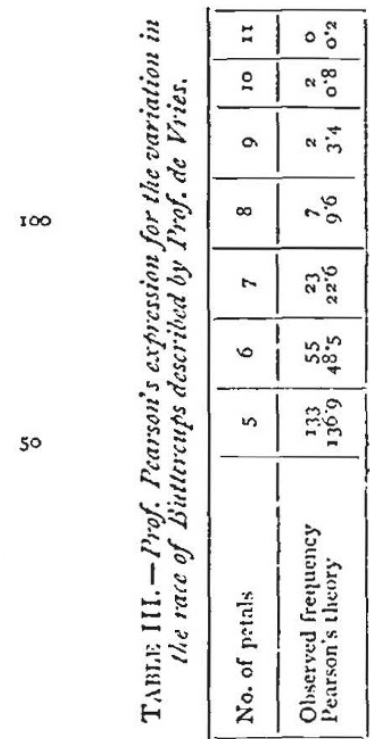

number of petals is five, and that no buttercups whatever have less than fire petals, though a considerable number have more than five; and here again you see the way in which Prof. Pearson's formula fits the observations.

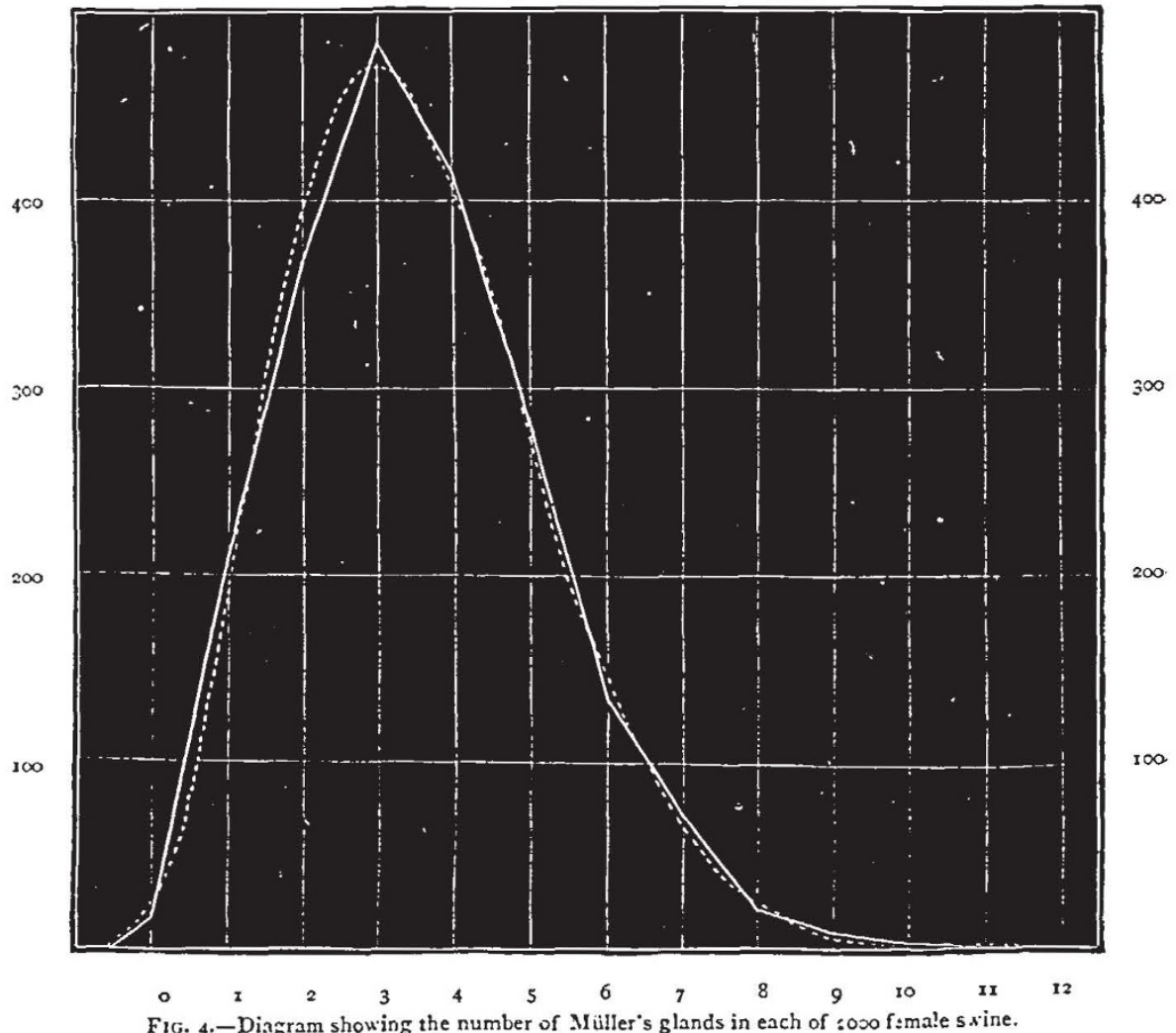

Fig. 4.-Diarram showing the number of Müller's glands in each of $: 000 \mathrm{f}: \mathrm{male} \mathrm{s}$ sine. 
You see that if this diagram (which is based on very few specimens) really represents the law of variability in these buttercups, no amount of natural or other selection can produce a race with less than five petals out of them. While it is con. ceivable that selection might quickly raise the normal number of petals, it could not diminish it, unless the variability of the race should first change. ${ }^{1}$

These examples, which are typical of others, must suffice to show the way in which the theory of Chance, as developed by Prof. Pearsun, can express the facts of organic variation.

I think you will agree that they also show the importance of investigating these facts. Fcr of the four cliaracters we have examined, we have seen that two, namely human stature and the antero-lateral carapace length of Carcinus manas, vary so as to afford nearly equal material for selective modification in either direction; one character, the number of Mriller's glands in swine, offers distinctly greater facility for selective modification in one direction than in the opposite direction; and in the last character, the number of petals in a race of buttercups appears to offer scope for mudification in one direction only, at least by selection in one generation.

Knowledge of this kind is of fundamental importance to the theory of Natural Selection. You have seen that the new method given to us by Prof. Pearson affords a means of expressing such knowledge in a simple and intelligible form ; and I, at least, feel very strongly that it is the duty of students of animal evolution to use the new and powerful engine which Prof Pearson has provided, and to accumulate this kind of knowledge in a large number of cases.

I know that there are people who regard the mode of treatment which I have tried to describe as merely a way of saying, with a ponpous parade of arithmetic, something one knew before. This criticism of Prof. Pearson's work was actually made to me the other day by an eminent biologist, whose name I will not repeat. If there be any here who hold such an opinion, I would ask them to read Mr. Francis Galton's Essays on IIeredity; where a simple and quite unexpected relation between parents and offspring is shown to be a direct con sequence of the fact that they vary by chance. This is the first and the most striking deduction from the mathematical theory of organic variation. but it is not the only one. It is enough, however to show that the new method is not only a simple means of describing the facts of variation, which facts rery few people knew before, but it is a powerful instrument of research, which ought to be quickly and generally adopted by those who care for the problems of animal evolution.

I think I have said enough to convince you how entirely Prof. Pearson's method promises to confirm the assertion that organic variation obeys the law of chance.

The other objections to Darwin's theory are not so easily. answered. It is said that small variations cannot be supposed to affect an aninal's chance of life or death; but few persons have taken any pains to find out in any given case whether the death-rate is in fact affected by small variations or not. It is said that the process of Natural Selection is so slow that the age of the earth does not give time for it to operate, but I know of few cases in which any attempt has been made to find out by actual observation how fast a species is really changing.

I can only attempt to discuss the importarce of small variations, and the rate of organic change, in the one case which I happen to know: The particular case I have nyself studied is the variation in the frontal breadth of Carcinus manas."

During the last six years my friend, Mr. Herbert Thompson, and I have studied in some detail the state of this character in the small shore-crabs which swarm on the beach below the laboratory of the Marine Biological Association at Plymouth.

I will show you that in those crabs small changes in the size of the frontal breadth do, under certain circumstances, affect the death-rate, and that the mean frontal breadth among this race of crabs is, in fact, changing at a rate sufficiently rapid for all the requirements of a theory of evolution.

In Table IV. you see three determinations of the mean fronta brealth of these crabs, expressed in terms of the carapace-length takeil as 1000. You see that the mean breadth varies very

1 Of course we know that selection does change the variability of a race. $\because$ In 1 Egt I gave an account of the variation of this dimension in female specimens of various sizes (Roy. Soc. p,oc, vol. Ivii.), and I put forward an hyputhesis of the amount of selective destruction due to variation in thi character. That hypothesis neglected several importalt facts wh ch I now know, and wa: open to other objections. I desire to replace it by the result

No. I 508, voL. 58] rapidly with the length of the crab, so that it was necessary to determine it separately in small groups of crabs, such that the length of no two crabs in a group differed by more than a fifth of a millimetre. The first column of the table shows you the mean frontal breadth of twenty-five such groups, between ro and 15 millimetres fong, collected in 1893 . These crabs were measured by Mr. Thompson. The second column shows you the mean frontal breadth in twenty-five similar groups of crabs, collected in IS95, and also measured by Mr. Thompson. You see that in every case the inean breadth in a group of crabs collected in 1895 is less than it was in crabs of the same size collected in IS93. The third column contains the result, so far as it is yet obtained, of my own measurement of crabs collected this year. It is very incomplete, because the I $\$ 95$ crabs were collected in August and September, and I was anxious to com. pare them with crabs collected this year at the same season, so that there has not yet been time to measure the whole series. The measurements are sufficient, however, to show that the same lind of change has taken place during the last three years as that observed by Mr. Thompson in the interval between 1893 and IS95. Making every allowance for the smallness of the numbers so far measured this year, there is no doubt whaterer that the mean frontal breadth of crabs from this piece of shore is considerably less now than it was in I $\mathrm{S}_{95}$ among crabs of the same size. ${ }^{1}$

Tabie IV.-The Mean Frontal Breadth ratio of Mrale Carcinus monas from a farticular patch of beach in Plymouth, in the years i 893 , iS95, and isgS.

\begin{tabular}{|c|c|c|c|c|}
\hline \multirow{2}{*}{$\begin{array}{l}\text { Length } \\
\text { of } \\
\text { carapace. }\end{array}$} & \multicolumn{4}{|c|}{ Nean frontal breadth in terms of carapace length $=1000$. } \\
\hline & (Thompsun). & $\begin{array}{c}1895 \\
\text { (Thompson). }\end{array}$ & (W'eldon). & $\begin{array}{l}\text { No. of } \\
\text { crabs in } \\
\text { the r } 8933 \\
\text { group. }\end{array}$ \\
\hline 10.1 & 816.17 & Sog.OS & - & - \\
\hline $10 \% 3$ & S12.06 & $\mathrm{So}_{4} \cdot \mathrm{S}_{2}$ & $\ldots$ & - \\
\hline $10 \% 5$ & $\mathrm{So}_{7} \cdot 37$ & $\mathrm{SO}^{\circ} \cdot 27$ & - & - \\
\hline $10 \% \frac{7}{7}$ & Sos.96 & 80169 & - & - \\
\hline $10 \% 9$ & $\mathrm{So}_{5} \cdot 07$ & $799^{\circ} 27$ & - & - \\
\hline II I I & So2.50 & $794^{-1} 2$ & 784.25 & 4 \\
\hline $11 \cdot 3$ & $798 \cdot 18$ & $792 \cdot 38$ & $787 \cdot 36$ & II \\
\hline II $\frac{5}{5}$ & $797 \cdot 19$ & 788.83 & 784.00 & 9 \\
\hline 117 & 794.28 & $785^{\circ} 29$ & $782: 44$ & 16 \\
\hline II -9 & $79 \mathrm{I} \cdot 45$ & 756.53 & 780.09 & II \\
\hline $12 \cdot \mathrm{I}$ & $758 \cdot 38$ & $780 \cdot 6 \mathrm{I}$ & $775 \cdot 25$ & I6 \\
\hline 123 & 78398 & 779 '50 & 773442 & 12 \\
\hline $12 \cdot 5$ & $783^{\circ} \subseteq 9$ & 776.50 & $767^{\circ} 00$ & I I \\
\hline 127 & $783 \% 5$ & 773443 & $772 \cdot 43$ & I 4 \\
\hline 129 & $777 \cdot 38$ & $773 \cdot 63$ & 764.67 & I5 \\
\hline $13 \cdot 1$ & 776.63 & $77 \mathrm{I} \cdot 6 \mathrm{I}$ & $760 \cdot 13$ & 16 \\
\hline $13 \cdot 3$ & 774.60 & $766 \cdot 21$ & $761 \cdot 29$ & 7 \\
\hline $13 \% 5$ & $7669 t$ & $7633^{\circ} 96$ & $759^{\circ} 5^{6}$ & 16 \\
\hline 13.7 & $767 \cdot 63$ & 762.00 & $757^{\circ}$ & I6 \\
\hline $13 \cdot 9$ & 76373 & 759.40 & $756 \cdot 10$ & 10 \\
\hline $14 \cdot 1$ & 758.94 & $757^{\circ} 00$ & $742^{\circ} \circ 0$ & I3 \\
\hline $14 \cdot 3$ & 756.90 & 75577 & $747 \cdot 86$ & 7 \\
\hline $14 \%$ & $762 \cdot 60$ & $75+45$ & 744.44 & 9 \\
\hline 147 & 753.00 & $749^{\circ} 8$ & $739^{\circ} \cdot 22$ & 8 \\
\hline $14^{\circ} 9$ & $751 \cdot 32$ & $748 \cdot 03$ & $742 \cdot 8_{3}$ & 6 \\
\hline
\end{tabular}

These results all relate to male crabs. The change in female crabs during this time has been less than the change in male crabs, but it is, so far as my measurements at present permit me to speak, going on in the same direction as the change in male crabs.

I think there can be no doubt, therefore, that the frontal breadth of these crabs is diminishing year by year at a rate which is very rapid, compared with the rate at which animal evolution is commonly supposed to progress.

I will ask your patience for a little while longer, that I may tell you why I feel conficlent that this change is duc to a selective

1 I shall, of course, consider it my duty to justify this statement by more extenire measurement as soon as possible. In the meantime I may say that I have measured other small groups of crabs, male and female, from the same place, at different sezions of the years $x 395-99$, and the results agree with those recorcled in the table. 
destruction, caused by certain rapidly changing conditions of Plymouth Sound.

If you look at the chart, you will see that Plymouth Sound is largely blocked up, and its communication with the sea is narrowed by a huge artificial breakwater, about a mile long, so that the tidal currents enter it and leave it only by two openings. This huge nodern barrier has largely changed the physical conditions of the Sound.

On either side of Plymouth itself a considerable estuary opens into the Sound, and each of these estuaries brings down water from the high granite moorlands, where there are rich deposits of china clay. Those of you who know Dartmoor will re. member that in rainy weather a great deal of china clay is washed into the brooks and rivers, so that the water frequently looks white and opaque, like milk. Much of this finely divided china clay is carried down to the sea; and one effect of the breakwater has been to increase the quantity of this fine silt which settles in the Sound itself, instead of being swept out by the scour of the tide and the waves of serere storms.

So that the quantity of fine mud on the shores and on the bottom of the Sound is greater than it used to be, and is constantly increasing.

But this is not all. During the forty or fifty sears which have gone by since the breakwater was completed, the towns on the shores have largely increased their population; the great dockyard at Devonport has increased in size and in activity; and the ships which visit the Sound are larger and more numerous than they were. Now the sewage and other refuse from these great and growing towns and dockyards, and from all these ships, is thrown into the Sound; so that while it is more difficult than it uscd to be for

fine silt to be washed out of the Sound, the quantity thrown into it is much greater than it was, and is becoining greater every day.

It is well known that these changes in the physical conditions of the Sound have been accompanied by the disappearance of animals which used to live in it, but which are now found only outside the area affected by the breakwater.

These considerations induced me to try the experiment of keeping crabs in water containing fine mud in suspension, in order to see whether a selective destruction occurred under these circumistances or not. For this purpose, crabs were collected and placed in a large ressel of sea-water, in which a considerable quantity of very fine china clay was suspended. The clay was prevented from settling by a slowly moving automatic agitator; and the crabs were kept in under these conditions for various periods of time. At the end of each experinent the dead were separated from the living, and both were measured.

In every case in which this experiment was performed with china clay as fine as that brought down by the rivers, or nearly so, the crabs which died were on the whole distinctly broader than the crahs which lived through the experiment, so that a crab's chance of survival could be measured by its frontal breadth.

When the experiment was performed with coarser clay than this, the death-rate was smaller, and was not selective.

I will rapidly show you the results of one or two experiments The diagram (Fig. 5) shows the distribution of frontal breadths, about the average proper to their length, in 248 male crabs treated in one experiment. Of these crabs, 154 died during the experiment, and $9 t$ survived. The distribution of frontal breadths in the survivors is shown by the lower curve in the diagran, and you see that the mean of the survirors is clearly below the mean of the original series, the mean of the dead being above the original mean.

Two other cases, which are only examples of a series in my possession, show precisely the same thing. ${ }^{2}$

These experiments seemed to me to show that very finely

1 It is impossible in this place to give a full account of the experiments rcferred to, and a multiplication of mere small scale diagrams seems useless, so that only one of those exhibited when the address was delivered is here reproduced. divided china clay does kill crabs in such a way that those in which the frontal breadth is greatest die first, those in which it is less live longer. The destruction is selective, and tends to lower the mean frontal breadth of the crabs subjected to its action. It seemed to me that the finer the particles used in the experiments, that is to say, the more nearly they approached the fineness of the actual silt on the beach, the more selective their action was.

I therefore went down to the beach, where the crabs live, and looked at the silt there. This beach is made of moderately small pieces of nountain linestone, which are angular and little worn by water. The pieces of limestone are covered at low tide with a thin layer of very fine mud, which is much finer than the china clay I had used in my experiments, and remains suspended in still water for some time. Under these stones the crabs live, and the least disturbance of these stones raises a cloud of very fine nud in the pools of water under them. By washing the stones of the beach in a bucket of sea water, I collected a quantity of this very fine mud, and used it in a fresh series of experinents, precisely as I had before used china clay, and I obtained the same result. The mean frontal breadth of the survivors was always smaller than the mean frontal breadth of the dearl.

I think, therefore, that MIr. Thompson's work, and my own, have demonstrated two facts about these crabs; the first is that their mean frontal breadth is dininishing jear by jear at a measurable rate, which is more rapid in males than in females; the second is that this diminution in the frontal breadth occurs in the presence of a material, namely, fine mud, which is in. creasing in amount, and which can be shown experimentally to cront, and wh

1G. 5--Diagram showing the effect of china clay upon 248 male crabs. The upper curve shows the $S$
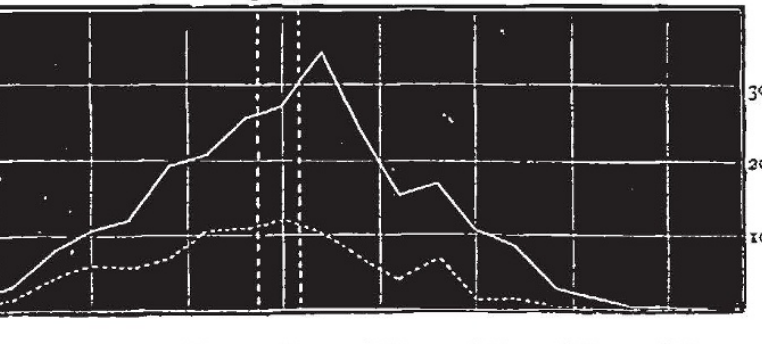

$+20+30+40$

distribution of frontal breadths in all these crabs; the dotted curve the distribution of fruntal breadth

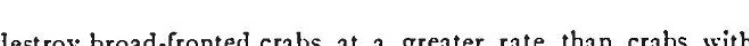
destroy broad-fronted crabs at a greater rate than crabs with narrower frontal margins.

I see no shadow of reason for refusing to believe that the action of nud upon the beach is the same as that in an experi. mental aquarimn; and if we believe this, I see no escape from the conclusion that we have here a case of Natural Selection acting with great rapidity because of the rapidity with which the conditions of life are changing.

Now, if we suppose that nud on the beach has the same effect upon crabs as nud in an aquarium has, we must suppose that every time this nud is stirred up by the water, a selective de. struction of crabs occurs, the broad-fronted crabs being killed in greater proportion than the narrow-fronted crabs.

Therefore, if we could take a number of young crabs, and protect them through a certain period of their growth from the action of this selective mud, the broad-fronted crabs ought to have as good a chance of life as the rest; and in consequence the protected crabs should contain a larger percentage of broad individuals than wild crabs of the same age; and the mean frontal breadth of such a protected population ought to be grenter, after a little time, than the mean frontal breadth of wild crabs, in which the broad individuals are being constantly destroyed.

It is difficult to perform this experiment, because one cannot know the age of a crab caught on the shore. But so far as one can judge the age of a crab by its length, I can show jou that the thing which ought to happen, on the hypothesis that such selective destruction is going on, does actually happen.

I established an apparatus consisting of some hundreds of

NO. I 508 , VOL. 58] 
numbered glass bottles, each bottle being provided witls a constant supply of clean sea-water by means of a system of glass syphons. Into each of these bottles I placed a crab from the beach. After a considerable number of deaths had occurred, a series of crabs was finally established, each crabliving in a num. bered bottle, until it had cast its shell. The process of moulting involves no distortion of the carapace, which could affect the measurements concerned, and thereforc each cast shell was care. fully measured. The measurements of these shells were carefully compared with measurements of wild crabs of the same size, and the mean frontal breadth of these shells was a little less than the mean breadth in wild crabs of corresponding length. 1

After each crab had moulted, it was left in its bottle until i had grown and had hardened a new shell. It was then killed and measurcd, and the measurements obtained were conspared with measurements of wild crabs of corresponding size. This time the captive crabs were unmistakably broader than wild crabs of their own size, and there were a few of the protected crabs which were very remarkably broad. The distribution of abnormalities before and after moulting is shown in Fig. 6 .

This is precisely the result which we ought to have obtained, if the hypothesis suggested by the study of mud were true. By protecting crabs through a period of their growth, we ought to raise the mean frontal breadth, and to obtain a greater percentage of abnormally broad crabs, and that is what we havc seen to occur.

Of course, this experiment by itself is open to many objecticns. The estimate of age by size is a dangerous proceeding, and it is difficult to exclude the possibility that confinement in a bottle may directly modify a crab during the critical period of

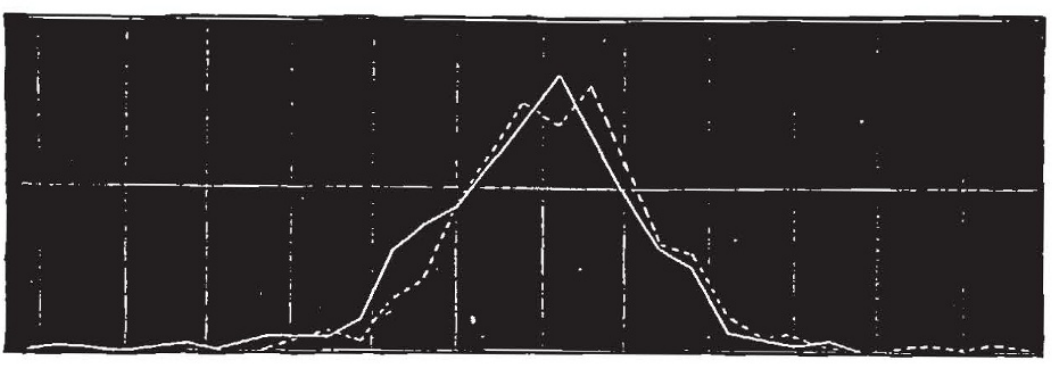

$\begin{array}{llllllll}-60 & -50 & -40 & -30 & -20 & -10 & 0 & +10+20+30+40+50\end{array}$

FıG. 6. - Distributicn of atnormality of frental breadih ratics in 527 female crabs before and after moulting in captivity. I he ccntitucus line shows the dis:ribution before, the dotted line after moulting.

moulting, and so on. All these points would have to be dis. cussed at greater length than your patience would bear, before we could accept this experiment by itsclf as a proof that some selective agent exists on the shore, which is absent from the bottles. At the same time, the result of this experiment is exactly what we should expect to find if such a selective agent did exist, and so it is in complete harmony with the evidence already put before you.

Of course, if the observed change in frontal breadths is really the result of selection, we ought to try to show the process by which this selection is effected.

This process seems to tc largely associated with the way in which crabs filter the water entering their gill-chambers. The gills of a crab which has died during an experiment with china clay are covered with fine white mud, which is not found in the gills of the survivors. In at least go per cent. of the cases, this difference is very striking; and the same difference is found between the dead and the survivors in experiments with mud.

I think it can be shown that a narrow frontal breadth renders one part of the process of filtration of water more efficient than it is in crabs of greater frontal breadth.

1 This was probably due to the death-rate during acclimatisation beirg selective. It was very difficult to keep the apparatus clean; and the deaths which occurred were in most cases due to the presence of putrescent deaths which occurred were in most cases
bits of food, which had not beer. removed.

A subsequent experiment was made wish the same apparatus, in which A subsequent experiment was made with the same apparatus, in which
crabs vere kept in putrid water until a large perct ntage bad diea : and the crabs $u$ ere kept in putrid water until a large perct ntage bad died and the
mean frontal breadih of the survivors was found to te distinctly less than the mean frontal breadth of the dead.

No. 1508 , voL. 58$]$
It would take too long to go into that matter now, and I shaj not attempt to do so. I will only now ask you to consider one or two conclusions which seem to me to follow from what I have said.

I hope I have convinced you that the law of chance enables one to express easily and simply the frequency of variations among animals; and I hope I have convinced you that the action of natural selection upon such fortuitious variations can be experimentally measured, at least in the only case in which any one has attempted to measure it. I hope I have convinced you that the process of evolution is sometimes so rapid that it can be observed in the space of a very few years.

I would urge upon you in conclusion the necessity of extending as widely as possible this kind of numerical stuáy. The whole difficulty of the theory of Natural Selection is a quantitative difficulty. It is the difficulty of believing that in any given case a small deviation from the mean character will be sufficiently useful or sufficiently harmful to matter. That is a difficulty which can only be got rid of by determining in a number of cases how much a given variation does matter; and I hope I have shown you that such determination is possible, and if it be possible, it is our duty to make it.

We ought to know numerically, in a large number of cases, how much variation is occurring now in aninals : we ought to know numerically how much effect that variation has upon the death-rate; and we ought to know numerically how nuch of such variation is inherited from generation to generation. The labours of Mr. Galton and of Prof. Pearson have given us the means of obtaining this knowledge : and I would urge upon you the necessity of obtaining it. For numerical knowledge of this kind is the only ultimate test of the theory of Natural Selection, or of any other theory of any natural process whatever.

SECTION G. MECHANICAL SCIENCE.

OPENING ADDRESS BY SIR JOHN WOLFE BARRY, K.C.B., LL.D., F.R.S., PRESIDENT OF TIE Section.

APART from all the other considerations which so favourably affect this Congress, I think, so far as Section G is concerned, that we are fortunate in meeting in this ancient city; which has so much of special interest for en. gineers and for others interested in applied science.

(I) I propose, therefore, to say a few introductory words about Bristol and its neighbourhood from the point of view of this section of the Association, but it is far from my intention to either criticise the past work of the Corporation in relation to their dock enterprises or to volunteer advice to them with re. spect to possible works of improvement.

Bristol is, at this moment, of great commercial importance, as indicated by the value of its imports and exports, and occupied an eren more important relative position among British ports at a time when the ports of Liverpool, Glasgow, Cardiff, or South. ampton were almost, or altogether undeveloped. So far as Customs Revenue is concerned Bristol now stands third, and in regard to the gross value of her sea-borne trade she is thirteenth among ports of the United Kingdom.

It is unnecessary, and it would be foreign to the objects of Section G, to attempt to trace the economic reasons which have caused the long-continued importance of Bristol, or to account for the rapid growth of other ports more or less competitive with her. All such causes are to be found, at least to a great extent, in considerations apart from the merely physical characteristics of the sea, river, or land at the various sites, as, for example, in propinquity to markets or centres of production, in situation relatively to population or to means of distribution, in individual or collective enterprise, in enlightened or unenlightened adninistration,

These circumstances have, in truth, at least as much if not more influence in deternining the history and prosperity of ports than what are termed natural advantages of respeciive sites, by which I mean such matters as protection frcm winds 
and currents, depth of water in the port itself and in its approaches from the sea, the possession of soil adapted to the foundations of docks or quays, and ready access to suitable materials for cheap and efficient construction.

While recognising to the full the great adiantages of such physical endowments in the development of a great port, one cannot but remember that they forni only part of the problem, and that the business of engineers is to modify and direct the great forces and characteristics of nature for the use and con. venience of mankind. IVe have, in fact, to make the best of a locality which may or may not be promising in the first instance, and history shows us that there are few places which are hopeless for our purposes. Thus while, on the one hand, we see many harbours in this country which inherit from nature every feature to be desired for the establishment of a port, but which remain useless for that object, so, on the other hand, we find many of the great centres of trade established in situations which possessed no such advantages, and where almost everything has had to be supplied by painful exertion and great expenditure.

As examples of these facts, I may point to the remarkable progress of many commercial ports situated in localities which were originally the reverse of promising from an engineering point of view-to Glasgow, where twenty.six millions sterling in value of exports and imports are annually dealt with in ships of the largest draught, though it is placed on a river which only fifty jears ago was nearly dry at low water for a distance of ten miles below the present docks-to Newcastle, with a present trade of $13 \frac{1}{2}$ millions sterling, which within the memory of this generation was approached by a shallow river, entering a muchexposed part of the North Sea over a dangerous sand bar. Sixty years ago the Tyne could only receive (and that only at high water) a small class of coasting ressels, whereas it is now navigable for deep.draughted vessels for a distance of thirteen miles from the sea. The break waters also at Tynemouth, which have been constructed under great difficulties on a coast without a single natural encouraging characteristic, not only make a valuable harbour of refuge, but have, practically speaking, removed the external bar.

In a similar way, as evidence of the truth of $\mathrm{my}$ proposition, I might point to a multitude of other instances; to the great docks of Buenos $\Lambda$ yres, which city, when I knew it twenty years ago, could not be approached within seven or eight miles by sea-going ships of fifteen or sixteen feet draught; to Calcutta, dependent on the dangerous navigation of the Hooghly, includ. ing the dreaded James and Mary shoals; to the creation of the port of Manchester, forty five miles from the sea, approached by a tide-locked canal which has cost thirteen or fourteen millions of money in its construction; to the great recent deselopments of Rouen, Dunkirk, Antwerp, and Ansterdam ; to the improvements of the Danube and the Mississippi. In all of these cases the natural characteristics of the localities were quite unsuited to the requirements of an advancing trade in modern vessels, but the inexorable demands of commercial shipping have created the supply, at the hands of engineers, of improvements and modifications of nature, which are so large and important that, to an unprofessional eye, they might now almost appear, at least in some of the cases which I have mentioned, to be physical characteristics of the locality.

I think that we may safely say that trade will produce the required accommodation, and that accommodation in itself will not create or attract trade.

Bristol is a case in point, and it is interesting to us at this meeting to note, however briefly, some of the important works which have altered and are altering its capacity as a port. At the end of last century Bristol and its capabilities were, as they have been almost ever since, the battlefield of civil engineers, and we know that reports and projects were made by most of the men who were then recognised as authorities. The diversion of the river Avon and the construction of the floating harbour of Bristol, which were carried out under the advice of Villiam Jessop in the years from 1804 to 1809 , were boldly conceived and ably executed. The result of the diversion of the Avon by means of what is still known as the New Cut enabled the old course of the river to be made into a floating harbour of about 71 acres, of which 57 acres are available for vessels of considerable size. The total cost seems to have been about $600,000 l$. Though the greatest draught of water in the floating harbour (some 20 feet) and the dimensions of the original locks ( 150 feet long and $3^{6}$ feet wide) may appear to us at the close of the nineteenth century somewhat insignificant, they were, no doubt, up to the estimated requirements of that day, and I think we can recognise in Jessop's work the impress of a great mind.

The Cumberland Basin was deepened and improved, and the lock accommodation was increased by Brunel in 1850 by the construction of a lock, $35^{\circ}$ feet long and 62 feet wide, and again by Howard in 1871, who made another lock, 350 feet long, 62 feet wide, with 23 feet of water at high water of neap tides.' This is the present limitation of the access of shipping to the town docks, and though we realise its insufficiency for modern vessels, we can appreciate the energy of those who have gone before us, and who found the funds for or designed works which have for so many years well fulfilled their purpose.

The approach to Bristol from the sea-that is to say, from King Road in the Bristol Channel-is certainly unpromising for large ships, and indeed, when contemplated at low water appears not a little forbidding. Something has been done, and more is now in progress, towards straightening, deepening, buoying, and lighting the tortuous course of the Avon below Bristol. More, no doubt, would have been undertaken in former years, if the great rise of tide in the river had not pro. vided, at spring tides, a depth and width for navigation which were sufficient for practical purposes, until the size of modern ships imperatively demanded increased facilities of approach. I think it is a remarkable thing that ressels of 3000 tons burden, 320 feet in length, and drawing 26 feet of water, succeed in reaching Bristol, and that the trade in the heart of the city con. tinues to increase.

Those acquainted with the strong tides of the Avon, or with its bends, which do not exceed in places a radius of 800 feet, and, lastly, with what might be the consequences of a long vessel grounding in a channel which has only a bottom width of 100 feet, cannot but recognise the skill and nerve of the pilots in navigating large vessels from King Road to Bristol. This is done by night as well as by day, and so successfully that the rate of insurance for Bristol is no inore than it is for Ayonmouth or Portishead, the entrances of which are in the Severn, or than for many ports situated on the open sea.

We have similar examples of what can be done by the systematic development of pilotage skill in the IIooghly, the River Plate, the Yangtse Kiang, the Mississippi, and other rivers where special men have been evolved, as it were, by the demand, and navigate with safety and success channels which are so full of dangers that they might well appear impracticable. Experience, indeed, shows us that, given a trade and a depth of water rendering access possible, ships will make their way to ports through all kinds of difficulties and with a wonderfully small margin of water under their keels, reminding one of the boast of the Mississippi captain that he could take his steamer wherever the channel was a little damp.

To return, however, to Bristol and the Aron; in spite of all efforts to keep pace with trading requirements, the time arrived, in 1868 , for lproviding improved dock accommodation, which would avoid the navigation of the Avon, and at the same time afford deeper locks and more spacious quays than could be given in Bristol itself. The Avonmouth and Portishead docks accord. ingly were built between 1868 and 1878 , and acquired by the Corporation in 1884 . Both are fine works for their period; but even in their case the rapid development of modern shipping has occasioned a demand for enlargements of the facilities which they afford. Accordingly, a matter which is again agitating Bristol is still further dock accommodation, and there has been a sharp contention whether this should be effected by what is implied in the somewhat barbarous word "dockising" the Aron, or by new docks at King Road. Dockising implies the construction of a weir and locks at Aronmouth, so that the Avon would be impounded and make one sheet of water nearly six miles long to Bristol, the natural discharge of the river being provided for by outfall sluices, while the alternative of dockising the Aron is to be found in great additions to the docks either at Avonmouth or Portishead.

In the peaceful atmosphere of Section G, I will not enter upon the various aspects of these antagonistic proposals, and will merely say that I have no doubt that in some way Bristol will keep ahead of what is wanted, and that I wish the city and the engineer who may carry out any of the ideas which may be eventually adopted every success and satisfaction in such important undertakings.

(2) Leaving, then, for the present all local considerations, and seeing that a large part of my own work has lain in the

$$
\text { No. I } \left.508 \text {, vOL. } 5^{8}\right]
$$


construction of new docks and in the alteration of old docks, I propose now to say a few words on what appear to me to be at present the salient points on these subjects in relation to the growth and the requirements of our merchant navy.

In the first place one cannot but be struck with the great demands which have come with some suddenness on the present generation for increased dock and quay accommodation. The British people are the chief carriers of the world, and are indeed those "that go down to the sea in ships, and occupy their business in great waters." This can be appreciated when we consider that annually our over-sea import registered tonnage is thirty.four millions, and our export registered tonnage is thirty-eight millions. Our coastuise traffic amounts to sixtythree million tons per annum, making together a tonnage to be dealt with of one hundred and thirty-five million tons. If we add to these figures the tonnage of vessels in ballast and the number of calls of those vessels in the coasting trade which touch at sereral ports in the course of one vojage, we must add a further fifty-five millions of tonnage, making a total of one hundred and ninety millions of tonnage using our ports yearly ; and if we divide these figures by, say, three hundred days, to provide against more or less idle days, bad weather, and the jike, we have the result of six hundred and thirty-three thousand tons per diem entering and leaving our ports. If we assume an arerage ship of three hundred registered tons, which is probably not far wrong, we have about two thousand one hundred trading vessels entering or leating our ports daily-a flotilla of startling numbers.

In truth, the magnitude of our mercantile navy, as compared with that of other countries, is astonishing. We have ten and a half millions of tons, against a total of thirteen millions of tons belonging to all the other nations of the world, in which are included three millions of tons of steam vessels engaged in the lake and river traffic of the United States. Descending to particulars, our nerchant fleet is elcren and a half times that of France, seven times that of Germany, eighteen times that of Russia (in Europe), two and three-quarter times that of the United States (inclusive of the craft on the great lakes), six and three.quarte times that of Norway, fourteen times that of Italy, and fourteen times that of Spain. Out of our total tonnage of ten and a half millions, six and three.quarter millions are steam ressels, and the proportions in relation to the steam tonnage of the other countries above referred to are approximately the same.

Again, it is instructive to note how small a proportion of the trade of other countries, even including coasting traffic, is carried in ships belonging to the country in question. Thus, whereas we as a nation convey in steamships 76 per cent. of the aggregate tonnage of our own ports, only the following proportions of the total trade of other nations are carried by the shipping of each country in question :-

\begin{tabular}{|c|c|c|c|c|c|c|}
\hline France & $\cdots$ & $\cdots$ & ... & about & \multicolumn{2}{|c|}{30 per cent. } \\
\hline Italy & $\cdots$ & ... & $\cdots$ & ", & 19 & " \\
\hline Germany & $\cdots$ & $\ldots$ & ... & , & 43 & ", \\
\hline Russia (in & Europe) & $\cdots$ & $\cdots$ & $"$ & 7 & , \\
\hline Norway & .. & $\cdots$ & ... & , & 56 & , \\
\hline Sweden & $\cdots$ & $\cdots$ & $\cdots$ & s & 29 & " \\
\hline Holland & & $\cdots$ & $\cdots$ & ," & & ", \\
\hline United Sta & tes (over & -sea) & $\ldots$ & ,, & I5 & ," \\
\hline
\end{tabular}

Further, it is a recognised fact that a very large part of the balance of the above proportions is conveyed in British ships frequenting the various foreign ports and acting, as I have said, as the ocean carriers of the world.

Thus in the best returns available I find that British shipping conveys the following proportions of the over-sea commerce of other countries :-

$\begin{array}{lcccccc}\text { Italy } & \ldots & \ldots & \ldots & \ldots & 44 & \text { per cent. } \\ \text { Germany } & \ldots & \ldots & \ldots & \ldots & 3 \delta & , \\ \text { Russia } & . . & \ldots & \ldots & \ldots & 57 & , \\ \text { Norway } & \ldots & \ldots & \ldots & \ldots & \text { I } & , \\ \text { Sweden } & \ldots & \ldots & \ldots & \ldots & 27 & , \\ \text { Holland } & \ldots & \ldots & \ldots & \ldots & 54 & , \\ \text { United States } & \ldots & \ldots & \ldots & 60 & \text { (', } \\ \text { France } & \ldots & \ldots & \ldots & \ldots & \text { (not given) }\end{array}$

The experience of the Suez Canal again tells the same tale, for of the total tonnage passing through that international waterway 66 per cent. is British. This is nearly seven times that of the shipping of the next largest contributor, which is Germany, and nine times that of France.

No. I 508 , voL. 58]
This vast amount of carrying trade is in British hands, because we can do it cheaply as well as efficiently. I believe that the whole of our commercial fieet is worked at a very narrow margin of average profit, though in the aggregate it forms one of the most important factors in our country's position among the nations of the world.

We are often reminded of how greatly the value of our imports exceeds that of our exports; but we should not forget that the profit on the transport of both gnes chiefly to the British nation as shipowners, in addition to the profit which is earned by them in the carriage of merchandise from one foreign port to another.

What an important thing it thus is to the prosperity of this country, not merely that our own ports should be convenient and adequate to all demands, but that our ship-huilders should be able to keep pace with the demands of this huge transport traffic ! We find in this connection that we add about half a million of tons of shipping annually to our register, and that we lose about 250,000 tons annually by wreck and by vessels becoming old or obsolete, so that, as a matter of fact, the average annual increment of our mercantile navy for the past twelve years is about a quarter of a million of tons.

The remarkable development within recent years in the cheapness of steam navigation, the improved methods of building and rigging of sailing ships, and various economic causes have resulted in a large increase of the average size of ship engaged in orer-sea voyages with a comparative diminution in the number of the crews of each description of vessel. Greater draught of water is consequently demanded, and as a better knowledge of ship.building has indicated that the beam of ships can be con. siderably increased without involving greater resistances, we may' expect to see ships to increase not only in length and depth, but also in width.

The largest steamer twenty years ago (excepting of course the Great Eastcrn, which was a magnificent conception, though in adrance of her time and its requirements) was, I beliere, the Ci/y' of Berlin, of 5500 tons burden. Her length was 488 feet, and her (Iraught and bean were 25 feet and 44 feet respectively. At the present time the Kaiser Wilhelm der Grosse is 625 feet long, her beam is 66 feet, and her draught is 27 feet, and we know that these dimensions will soon be exceeded.

A modern liner now being built will have a length of 70.4 feet (or 24 feet longer than the Grcat Eas/ern) with a beam of $6 S$ feet and a draught of $28+\frac{1}{2}$ feet. The great steamers for the transport of cattle are $5 \delta_{5}$ feet long, 64 feet beam, and 30 feet draught and upwards, carrying 14,000 tons of cargo. Some of the large sailing ressels carry over 6000 tons dead weight and draw $28 \frac{1}{2}$ feet. Ships of war, though not so long as liners, have a beam of 75 feet with a draught of 31 feet, and though in the commercial marine we need not perhaps anticipate any great further increase of draught of water, the demand for which is largely governed by what is available in foreign ports or rivers and in the Suez canal, the fact that men-of-war can, with Jue regard to economy of propulsion, be built with great width of beam in proportion to length, seems to indicate that we must be prepared in the future for a considerable increase of bean for cargo-carrying vessels.

We have further to note that, owing, no doubt, to the vas? improvements of marine steam engines and boilers realising unlonked-for economy in the combustion of coal, steam vessels are supplanting all but the largest class of sailing vessels as carriers of commerce, almost as rapidly as they did forty or fifty years ago in the conveyance of passengers and as ships of war.

In I S97, out of a total shipping trade (cargoes and ballast) dealt, with in ships of all nations at the ports of the United Kingdom, amounting to ninety millions of tons, eighty.one millions of tons, or 90 per cent., were convesed by steam ressels; whereas, in I 885 , out, of a total of sixty.four millions of tons, fifty millions of tons, or $7 \delta$ per cent., were in steamers. If we take, howerer, the tonnage of cargoes and ballast convejed to and from her own ports by British ships only; we find that in 1897, out of a total of sixty-four millions of tons, sixtyone millions of tons, or 95 per cent. were in steam vessels; whereas, in 1885 , but 85 per cent. of the total tonnage conveyed by British ressels was in steamships.

Of the tonnage of vessels built in the United Kingdon in $\mathrm{ISS}_{5}, 50$ per cent. Were steamers, but in $\mathrm{I} \delta 97$ the proportion was 86 per cent.; and to sum up, we find that in the commercial fleet of the United Kingdom and British Possessions, as between 1887 and 1897 , sailing, ships bave decreased 16 per 
cent. in number and have, in spite of the building of a certain number of exceptionally large vessels, decreased 9 per cent. in average size; while steamers have increased 23 per cent. in number and 16 per cent. in average size. The total sailing tonnage has decreased in the samie period by 24 per cent., and the steam tonnage has increased by 36 per cent.

The problems thus confronting us, as results of the increased size of all descriptions of over-sea steamships, require much consideration from an engineering point of view, and are further puzzling, and will continue to puzzle, our financial authorities, without whose aid the engineer can do but little.

We ask, Where is all this expansion of requirements to stop, and how far are we justified in extending our view of the wants of the future from the contemplation of the conditions of the present and of what has occurred in the past? This is un. doubtedly a difficult question, and he would be a bold man who thought that we had reached finality in the size of ships. Bound up with this consideration are not merely matters of first cost of the accommodation to be provided, but also of the annual expenses in working and maintenance, not only of the docks themselves, but in what is perhaps of more importance, viz. the preservation of sufficiently deep and wide approaches to them.

Apart from length, depth, and beam, the midship cross section of modern cargo ships has altered conipletely of late years, and is now nearly as rectangular in shape as a packing.case, excepting only that at the bilges the sides and floor are joined by a curve of small radius. The keel has almost disappeared, and bilge keels are often added. The result of these alterations of shape in the ordinary hulls of tradling ships is that the sills and sides of nany locks and entrances are now unsuited to what is wanted, and consequently their original power of accommodating vessels is most seriously diminished.

Until lately it was generally considered that locks 600 feet long, So feet wide, and 26 feet deep were sufficiently capacious, with some margin for futurc wants; but I think we inust now go further in length and depth, and not improbably to some extent in width. We find that at Liverpool the Dock Board have ordered vestibule lasins to act as locks I 150 feet long and 520 feet wide, with entrances 100 feet wide and 32 feet deep and somewhat similar dimensions were talked of for the entrance lock of the recently proposed Windsor Dock at Penarth, which was intended to be 1000 fect long, 100 feet wide, and 34 feet deep at neap tides.

Again, apart from the question of locks and entrances, the older docks themselves are beginning to be found too shallow and too narrow for modern ressels. In docks which are deep enough at spring tides and too shallow at neap tides, and which are opened to the "tide of the day," much may be done to improve the depth by systematic pumping, so as to keep the surface always at the level of high water of spring tides. By this expedient, large areas of old docks nmay be to that extent modernised at the expense, perhaps, of new entrance locks and the annual cost of pumping. This latter yearly outgoing is not an important matter. At Liverpool and Birkenhead 230 acres of nearly obsolete docks have been thus improved at a capital cost of about $96,000 l$. for pumping machinery and an annual expenditure of $6000 \%$. I am executing a similar inprovement by pumping in one of the smaller docks on the Thames, and contemplate it on a larger scale at an important dock there, and also at Hull.

The conditions of commerce now require also, in order to realise the necessary economy of transport, the greatest despatch, for demurrage on the large and expensive modern steam vessels is a most serious question. Thus there must now be no waiting for spring tides, or, if possible, for rise of tide on the day of arrival. Every steamer expects to discharge her cargo on to the quay without waiting for much stacking, still less for trucks; and under modern conditions dock work must be got through in one-third of the time which was considered proper ten or twelve years ago. From these reasons larger quays and warehouses, better railway approaches, jinproved sidings, and better machinery are all necessities, as well as deeper water and better approaches.

These demands have come on us, as I have said, not so much gradually as more or less suddenly, and the call for improved docks is general, and, in my opinion, it will be continuing.

Liverpool last year undertook to spend nearly five millions on such works, and we know of very many important projects at other places. Taking the expenditure within the past decade, and adding to it the authorised expenditure at Liverpool, at the great ports on the Bristol Channel, on the Thames, at South ampton, Hull, Middlesbrough, Hartlepool, Sunderland. the Tyne and its neighbourhood, at Grangemouth, the Fife Ports, at Glasgow, the Ayrshire Ports, the Cumberland and Lancashire Ports, and so round the British coasts to Preston, I roughly estimate an expenditure, either made during the past ten years or contemplated, of from 35 to 40 millions.

These are large figures, and we ask from whence will an adequate revenue come; for it is a more or less accepted fact that docks by thenselves do not produce more than a very moderate return on their cost, though, of course, there may be exceptions to every rule. Apart from the expenditure which has been undertaken much remains to be done, and the source of supply of the capital required is a highly important consideration. I venture to think on this point that we should learn to realisc that under modern conditions docks should be considered largely in the light of being railway stations for goods and minerals and, in many cases, for passenger traffic. Docks and quays, together with improved approaches from the sea, are, in fact, the means of bringing traffic to the railways (and, to a less degrce, to the canals) of a country, and should be looked upon as links in the chain of transport and inter. communication.

They are certainly as necessary adjuncts of a railway, at least in our country and in respect of goods and ninerals, as large stations and depôts are in all important towns.

The older view of our Parliament was that docks and railways should be in different hands; but I much question whether this idea should now commend itself. It is difficult, as I have said, for a dock enterprise standing alone to make any considerablc return on its cost, and though it is true that capital can be found under guarantees of an already developed trade by some of the great Dock Trusts, such as at Liverpool or Glasgow, the return is but a modest one, and not such as is likely to tempt capitalists to new ventures in constructing or enlarging many of the docks whicls stand in need of inprovements.

On the other hand, a railway company which gets a fairly long lead for the goods to and from a dock can afford to look at the matter of expenditure on docks with some liberality. IVe have conspicuous examples of great public benefit being affordel at Southampton and at Hull, where the docks have lately passed from the hands of financially weak companies depenclent only on dock dues, to the ownership of powerful railway companies. Similarly, several of the north-eastern ports besides Hull-the large docks at Grangemouth, Barry, Penarth, Garston, Flcetwood, and elsewhere-are further examples, amongst others, in which the revenue of railway companics has been spent on dock improvements with a spirit which would be otherwise unattain. able. A dock also mist necessarily be nowadays almost wholly dependent for its efficient working on the best understanding being maintained with the railway companies for the prompt and adequate provision of land transport, so that in that point of view also the two interests are one and should be recognised as such.

In the consideration of the advisability for concentration of ownership, there remain only the questions of safeguards against unfair treatment of competitive modes of transport, such as canal and road traffic, and provision against any improper results of monopoly of railway access. These, I think, can be provided by Parliamentary enactment, either by insisting on adequate access under proper conditions for all within reach, or, in any case, of inadequate facilities being accorded, by authorising the construction of other docks in the hands of competing railway companies or of other aggrieved parties, with in such cases railway privileges. With these safeguards the public could be efficiently protected, and, if this be so, I cannot but think that, cateris paribus, the trading community will be better served by docks directly connected with railway companies than by separate existences and management. On the one hand, I hope that those who administer the great railway undertakings will realise this community of interest, and, on the other, that Parliament will favour intimate financial relations betweein docks and railway's, instead of more or less srstematically dis. couraging such connection. This question is one which is peculiarly interesting here at Bristol, where the docks are in the hands of the Corporation, and where the railway companies carry the traffic, which, but for the docks, would be largely non-existent.

(3) Leaving now the question of modern docks and shipping,

No. I 508, VOL. 58] 
as to which, as I have said, Bristol is interesting to engineers, there are one or two other matters of history which appeal to Section $G$ in this locality. In the first place, Bristol was the birthplace of the Great Western Railway. 1. K. Brunel, its engineer, had previously, by public competition, been selected to span the gorge at Clifton by a suspension bridge of the then almost unrivalled span of 702 fect. Again, under the influence of Brunel, Bristol became the home of the pioneers of Transatiantic steamships, and the story of the initiation of the enterprise is thus told in the memoirs of his life. In I835, at a small convivial meeting of some of the promoters of the Great Western Railway, some one said, "Our railway to Bristol will be one of the longest in England," and Brunel exclaimed, "Why not make it the longest line of communication in the world by connecting it with New York by a line of steamers?" Out of this grew the Great Western steamship, and the history of the enterprise and of its success is too well known, at least here, to require any allusion to the steps by which it was brought about. Suffice it to say that, in spite of much discouragement, the Great IVestern-of the then unexampled size of two thousand three hundred gross tons, and with engines of unparalleled power-was launched at Bristol in 1837 , and ran successful and regular voyages till 1857 , when she was broken up.

In Section $G$ there are many who can appreciate the diffculties of such a new departure as the Great Western steamship, even if they had been confined to the design and study of a vessel and engines of unprecedented size; but it is not easy to realise the anxiety and trouble caused by the dictum of a man of science so universally adnired as Dr. Lardner, at the meeting of the British Association in this city in 1836 , that the whole idea of ocean narigation on royages as long as from Bristol to New York was at that epoch an abstract impossibility.

In these day's of criticism of the past, often involving the rehabilitation of individuals, it is interesting to note that Dr. Lardner's part in condemning beforehand the construction of the Great $I V^{\text {estern }}$ steamship and the ideas on which she was designed has been of late years unduly minimised. It has been said that all $\mathrm{Dr}_{\mathrm{r}}$. Lardner meant was to express a pious doubt as to the coinmercial prospccts of ocean navigation. I have carefully read the Procecdings of the time, and I an brought to the conclusion that his words and writings will admit of no such interpretation. Dr. Lardner's views, arrivcd at after calculation and reasoning, were precisely expressed and boldly and honestly enunciated by him. The words of the discussion here appear not to have been preserved, but in an elaborate article in a Quarterly keariew in 1837 , which is, I believe, admitted as having been written by Dr. Lardner, he said, "that in proportion as the capacity of a vessel is increased, in the same ratio, or nearly so, must the mechanical power of the engines be enlarged and the consumption of coal augmented." He based his views that success was impossible on principles which he supposed to be sound, but which were, in fact, assumptions-viz. that the resistance to the progress of a ship varied directly with her capacity, that a certain number of tons of coal were required per horse-power for the voyage across the Atlantic, and that, this being so, enough fuel could not be carried in a ship, however large she might be inade.

Brunel, on the other hand, contended that Dr. Lardner's views were fundamentally erroneous; for that, whereas the capacity of a ship increased in the ratio of the cube of her dimensions, the resistance to her progress varied more nearly as the square. Thus, by adopting a proper length, beam, and draught, a ship would not only carry coal for the journey to New York, but be commercially successful in respect of cargo and passengers.

It is interesting to note that $9 \mathrm{lbs}$. of coal per indicated horsepower per hour (as compared with our present $1 \frac{1}{2}$ to $2 \mathrm{lbs}$.) was the approximate coal consumption which was more or less accepted by both sides in the controversies of 1836 and 1837 .

We know now that the resistances encountered by a ship are not merely dependent on her dimensions, but comprise wavemaking at various speeds, bringing form and proportion of dimensions largely into the necessary calculations; but I want to point out that the line of divergence of the different views of Lardner and Brunel was sufficiently precise and quite crucial. It is true that Dr. Lardner, in later criticisms of 1837 , retreated somewhat from his position of 1836 , introducing more of the commercial aspect of the case and stating that no steam vessel could make profitable royages across the Atlantic, at least until marine engines were immenscly improved; but, even so, it seems clear that the fundamental matter at issue in I836 and 1837 , the period of Dr. Lardner's active criticism, was the question of the resistances increasing in the same ratio as the capacity. The results of these ex cathedri statements by Dr. Lardner about the Grcat Western, then in process of being built, must hase caused great anxiety to the promoters and much preliminary distrust of the ship on the part of the public. They were, unquestionably, honestly arrived at, howerer much they were due to reasoning on unascertained premises, and this latter is the rcason for my venturing now to refer once more to then. As a matter of fact, the ship started from Bristol in $18_{3} 8$, and arrived at New York in fourteen days with 200 tons of coal in her bunkers.

Let me remind you of another somewhat similar instance of the way in which the anxieties of engineers have been unnecssarily increased and public alarm gratuitously, though honestly; aroused. When the designs of the Forth Bridge- of which the nation, and indeed the world, is proud-had been adopted both by the Railway Companies who were to find the capital and by Parliament, a most distinguished man of science-the then Astronomer Royal-camc to the conclusion that the engineers had neglected certain laws which he enunciated respecting the resisting power of long struts to buckling, and that the bridge ought not to be constructed, as he considered that, to use his own words, "we may reasonably expect the destruction of the Forth Bridge in a lighter gale than that which destroyed the Tay Bridge." All this was stated no doubt from a strong view of public duty, in a letter to a public newspaper, though subsequently and frankly withdrawn. If the bases of his calculations were right, the conclusion might have been correct; but the fact was, that there was no foundation worthy of the name for the reasoning. Again, another distinguished mathematician publicly criticised the Forth Bridge with equal vigour, basing his views that it was fundamentally incorrect on another set of equally erroneous assumptions, maintaining again that it should not be permitted, hecause he proved by reasoning on those assumptions that it must be absolutely unsafe.

Once more, in ship-building, until MIr. IVilliam Froude, some years prior to 1875 , made his experinents by means of models on the highly difficult and otherwise almost insoluble causes of the retardation of ships and their behaviour in waves, beginning at the beginning, taking nothing for granted, and eliminating all elements of possible errors, little or nothing was known of the laws governing these questions. Laws had been laid down by high authorities as to the causes of retardation of ships, many of which, in fact, were not true, while some of the assigned causes were non-existent and some real causes were unrecognised. Mr. Froude was told that no information could be learnt from experi. ments on models which would be applicable to full-sized ships, and that ships must continue to be designed and engines built on data which, scientifically speaking, were assumptions. The outcome has been that Mr. Froude's a priori depreciated experi. ments with models have solved most of the questions relating to that branch of naval architecture; and at the present time every ship in the Royal Navy, and not a few in the merchant service, are designed in accordance with the data so gained.

Another example of hasty generalisation occurs to me, and that is on the important question of wind pressure. Tredgold, who undoubtedly was one of the soundest of engineers, laid down in I $\delta_{40}$ that a pressure of $40 \mathrm{lbs}$. per square foot should be provided for ; reasoning, no doubt, from the fact that such a pressure had in this country been registered on a wind gauge of a square foot or less in area. As a consequence, he assumed that the same force could be exerted by the wind on areas of any dimensions. Thus roofs and bridges, wherever any calculations of wind pressure were, in fact, made, were designed for a pressure of $40 \mathrm{lbs}$. per square foot of the whole exposed surface, and under the alarm caused by the fall of the Tay Bridge in 1879 , the piers of which were not probably strong enough to resist a horizontal pressure of one-fifth of such an amount, a further general assumption was made, and railway bridges throughout the kingdom were ordered by the Bnard of Trade in 1880 , acting no doubt on expert advice, to be in future designed, and are designed to this day, to resist $56 \mathrm{lbs}$. of horizontal wind pressure on the whole exposed area with the ordinary factors of safety for the materials employed, as if such horizontal strain were a working load.

It had, for a long time previously to this order of Gorernment being issued, been suspected that these small-gauge experiments were untrustworthy, and subsequent experiments at the Forth

กO. I 508 , voL. $\left.5^{8}\right]$ 
Bridge on two wind gauges of 300 square feet and of $1 \frac{1}{2}$ square feet respectively, indicated that with an increase of area the unit of pressure fell off in a very marked degree. Under the same conditions of wind and exposure, the larger gauge registered a pressure 38.7 per cent. less per square foot than the smaller gauge. I have been able to carry experiments further at the Tower Bridge by observing the pressure on the surface of the bascules of the bridge as eridenced hy the power exerted by the actuating engines. In this case we have a wind gauge of some 5000 feet in area, and it has been shown that, while small anemometers placed on the fixed parts of the bridge adjoining the bascules register from 6 to 9 lbs. per square foot, the wind pressure on the bascules is only from I to $1 \frac{1}{2}$ lbs. per square foot.

It is difficult to imagine the amount of money which has been expended in unnecessary provision against wind strains of $56 \mathrm{lbs}$. per square foot on large areas in consequence of this hurried generalisation from insufficient data. I know something of what the provision for $56 \mathrm{lbs}$. on the square foot for wind cost at the Tower Bridge, and I do not wish to mention it ; but if the public had been told that the dictum of experts, arrived at however hastily in 1880, was to be set aside in the construction of that bridge, all confidence would have been beforehand destroyed in it, and I suppose no Conmittee of Parliament would have passed the Act.

I have nientioned these matters, which could be added to by many similar instances in other branches of applied science, not for the sake of reviving old controversies or of throwing a stone at highly distinguished men, honoured in their lifetime and honoured in their memory, nor for the sake of criticising more modern inen of science or a Government Department. Still less do I wish to question the necessity and value of mathematical calculations as applied to the daily work of engineering science, but I recall the circumstances for the purpose of once more pointing out the extreme value of experimental research and of bespeaking the utmost caution against our being tempted to lay down laws based on unascertained data. We know the tendency. there has been at all times to generalise and to seek refuge in formulx, and we cannot but know that it is not at an end now. IVe ought to recognise and remember how few physical questions had been exhaustively examined sixty years ago, and may I say how comparatively few have even now been fundamentally dealt with by experiment under true scientific conditions? The in restigation of physical facts under all the various conditions which confront an engineer requires mich care, intelligence, time, and last, not least, not a little money. In urging the vital necessity of investigations, I am sure that I shall not be understood as decrying the value of the exact analysis of mathematics, but we must be quite sure that the premises are right before we set to work to reason upon them. IVe should, then, exert all our influence against rules or calculations based mertly on hypothesis, and not be content with assumptions when facts can be ascertained, eren if such ascertainınent be laborious and costly. In a word, let us follow sound inductive science, as distinguished from generalisations; for "Great is truth and mighty above all things."

In connection with this subject, I may congratulate the Association generally, and this Section in particular, that there is now more hope for experimental science and some endowment of research in this country than at any former time. The vital necessity of further work in these directions has long been recognised by men of science and was notably urged by Prof. Oliver Lodge. Last year, in no small degree owing to the exertions of Sir Douglas Galton, K.C.B., who presided over the British Association in 1895 , and brought the question very prominently forward in his inaugural address on that occasion, a highly influential deputation waited on the Prenier to urge that England should have a Public Ihysical Laboratory at which facts could be arrived at, constants determined, and instruments standardised. The importance of the questions which could be determined at such an institution in their influence on the trade and prosperity of the country, independently of the advancement of purely scientific knowledge, cannot well be exaggerated.

Our Government, while somewhat limiting the scope of the inquiry, appointed a small Conmittee to exannine and report on this highly important subject. It is no breach of confidence to say that the Committee, after taking much evidence, visiting a similar and highly successful institution on the continent, and studying the question in all its bearings, were convinced of the great public benefits which may be expected from such an institution, and have unaniniously reported in favour of its establishment.

I feel sure that we shall all earnestly hope that Government will carry out the views of the Committee, and I venture to suggest that each of us should use what influence he may have, to induce the Chancellor of the Exchequer to find adequate funds for an institution which may be of the greatest benefit not merely to scientific research, but to the commerce of these islands, threatened as it is on all sides by foreign competition of the most vigorous description - a competition which is supported by every weapon which the science of other lands can forge for use in the struggle. It being acknowledged that our own work in life is to deal with physical facts and apply them for the use of our fellow-men, we may have good hopes that at such an institution as I have indicated, directed, as it no doubt will be, by the highest scientific superintendence, we shall be able, at least far better than at present, to have a sound knowledge of many facts which are obscure, and to deal with the many new conoitions under which the applied science of the future will have to be carried on.

Those who know most of the problems of nature feel the more strongly how much remains which is unknown and realise how completely those who teach require throughout their lives to be always learners. Let each of us then in our special walk of life, seeking for further enlightenment on the various problems of our work and in the application of that science which we love, huinbly recognise that,

"All nature is but art, unknown to thee ;

All chance, direction which thou canst not see All discord, harmony not understood.

\section{INTERNATIONAL SEA FISHERIES CONGRESS A2' DIEPPE.}

THE movement for the international discussion of matters connected with the sea-fishing industry has made such progress during the past few years that a summary of the proceedings of the recent international congress held at Dieppe should interest readers of NATURE, especially as the regulation of the industry tends more and more to be determined in accord. ance with the evidence accumulated by scientific investigators. The Dieppe Congress was organisell by the Société d'Enseignement professionel et technique des l'ĉches Maritimes, and is the second international congress promoted by that society. The previous congress was held at Sables-d'Olonne in IS96, on which occasion Mr. (now Sir) John Murray was the British representative. More than 300 delegates assembled at Dieppe, among whom may be mentioned Mr. C. E. Fryer, of the Hoard of Trade ; Dr. J. II. Fullarton, formerly of the Scottish Fishery Board; Mrr. Walter Garstang, representing the Marine Biological Association; Mr. O. T. Olsen, of Grimsby ; Mr. Johnsen, of Hull ; Drs. Brunchorst and Bull, of Bergen; Dr. Malm, of Gothenburg; M. Tabary, of Ostend ; Prof. Vinciguerra, of Rome; Dr. Valle, of Trieste ; Dr. Kishinouye, of Japan ; Mr. Thorndike Nourse, of the United States; and of course a large number of French delegates representing the Government and various fishery societies and schools, fishing centres and municipalities, including MI. Roché, Inspector-General of Fisheries; Prof. Perrier, Baron Jules de Guerne, MIII. Lavieu. ville, of Dieppe; Canu, of Boulogne ; Odin, of Sables-d'Olonne ; Gourret, of Marseilles; and Le Seigneur, of Gransille. The proceedings of the Congress opened on the morning of September 2 with an address from the President, Prof. Ed. Perrier, Mlembre de l'Institut de France. The greater part of the President's address was deroted to an exanination of purely. French problems - the relative scarcity of steam trawlers and liners, the need of greater solidarity, of a spirit of co.operation and compromise among rival fishing industries, the present unsatis. factory arrangements-or lack of arrangements-for fishery research. This, he said, seemed to demand the creation of a central Fishery Board for France, similar to that of Scotland, which should be charged with the duty of coordinating the work of the numerous marine laboratories in which fishery research is now carried on without concerted aim. Proceeding then to matters of more general interest, he pointed out the advantages which would ensue if the study of plankton could be put upon an international basis by a regular organisation of the marine laboratories of different countries, or by international cooperation in deep-sea expeditions for the solution of problems

ヘ. I 508, VOL. 58 ] 